\title{
A family of C/EBP-related proteins capable of forming covalently linked leucine zipper dimers in vitro
}

\author{
Simon C. Williams, Carrie A. Cantwell, and Peter F. Johnson \\ ABL-Basic Research Program, National Cancer Institute-Frederick Cancer Research and Development Center, \\ Frederick, Maryland 21702-1201 USA
}

Mouse and rat genomic DNA libraries were screened by reduced stringency hybridization with the DNA-binding domain of the $c / e b p$ gene as a probe. Three genes were isolated that encode bZIP DNA-binding proteins (designated CRP1, CRP2, and CRP3) with strong amino acid sequence similarities to the C/EBP-binding domain. CRP2 is identical to the protein described recently by other groups as NF-IL6, LAP, IL-6DBP, and AGP/EBP, whereas CRP1 and CRP3 represent novel proteins. Several lines of evidence indicate that these three proteins, along with C/EBP, comprise a functional family. Each bacterially expressed polypeptide binds to DNA as a dimer with recognition properties that are virtually identical to those of C/EBP. Every member also bears a conserved cysteine residue at or near the carboxyl terminus, immediately following the leucine zipper, that at least in vitro allows efficient disulfide cross-linking between paired zipper helices. We developed a gel assay for covalent dimers to assess leucine zipper specificities among the family members. The results demonstrate that all pairwise combinations of dimer interactions are possible. To the extent that we have examined them, the same heterodimeric complexes can be detected intracellularly following cotransfection of the appropriate pair of genes into recipient cells. All members are also capable of activating in vivo transcription from promoters that contain a C/EBP-binding site. Our findings indicate that a set of potentially interacting C/EBP-like proteins exists, whose complexity is comparable to that of other bZIP protein subfamilies such as Jun, Fos, and ATF/CREB.

[Key Words: C/EBP-related protein; gene family; tissue-specific transcriptional activator; disulfide cross-links]

Received May 17, 1991; revised version accepted July 2, 1991.

The rapid accumulation of information about eukaryotic genes and their controlling factors has revealed an impressive degree of complexity within transcriptional regulatory processes. A simplistic a priori model, wherein a given cis-regulatory DNA sequence binds a single activator protein whose presence or absence in a cell unambiguously determines whether genes containing that sequence are transcribed or silent, has generally not been validated by the present data. Rather, most genes are controlled by a battery of sequence motifs that, together, specify appropriate transcription (Maniatis et al. 1987; Jones et al. 1988; Muller et al. 1988). In addition, regulatory proteins that bind to these motifs are increasingly found to occur in families whose members are related by common DNA recognition properties (for review, see Johnson and McKnight 1989), thus providing an additional level of complexity to gene control. The Fos and Jun (Ziff 1990 and references therein), cAMP response element binding/activating transcription factor (CREB/ ATF) (Hoeffler et al. 1988; Gonzalez et al. 1989; Hai et al. 1989), Oct (Clerc et al. 1988; Sturm et al. 1988; Scholer et al. 1989; Rosner et al. 1990), and MyoD (for review, see Weintraub et al. 1991) families represent a few well-char- acterized examples of this latter principle. Frequently, such groups are composed of both ubiquitously expressed and tissue-restricted members, where the latter function to control cell type-specific patterns of gene transcription.

In light of the existence of DNA-binding protein families, an understanding of the potential regulatory information inherent in a particular cis-regulatory sequence motif requires identification of the entire complement of proteins that recognize that sequence and knowledge of the cell types in which each member is present and active. The present study describes a family of factors related to the transcriptional regulatory protein CCAAT/ enhancer-binding protein (C/EBP). C/EBP is a heat-stable DNA-binding protein (Johnson et al. 1987) that belongs to the basic region-leucine zipper (bZIP) class (Landschulz et al. 1988a; Vinson et al. 1989) and that is present at elevated concentrations in the nuclei of terminally differentiated, postmitotic liver and fat cells (Birkenmeier et al. 1989; Umek et al. 1991). Cotransfection studies with the $c / e b p$ gene demonstrated that $\mathrm{C} / \mathrm{EBP}$ overexpression stimulates transcription from specific target genes that are expressed in mature hepatocytes 
(Friedman et al. 1989) or adipocytes (Christy et al. 1989; Herrera et al. 1989) and whose control sequences include C/EBP-binding sites. These observations suggest that C/EBP plays a role in activating cell type-specific expression of genes in fat, liver, and possibly additional tissues.

Southern blot experiments using a C/EBP cDNA probe initially failed to suggest the existence of a C/EBP gene family (Landschulz et al. 1988b). On the other hand, heat-stable DNA-binding activities that are indistinguishable from C/EBP were detected in extracts from tissues such as spleen, kidney, and brain (Cereghini et al. 1987; Lichtsteiner et al. 1987; P. Johnson, unpubl.). On the basis of the results of sensitive immunoblot assays, it has been established that spleen, kidney, and brain do not express the C/EBP polypeptide (W. Landschulz, P. Johnson, and S. McKnight, unpubl.), implying that proteins with functional homology to C/EBP must be present in these cell types. In addition, subsequent Southern blot experiments with rat DNA hybridized with a probe from the C/EBP DNA-binding domain at reduced stringency identified two strongly cross-hybridizing sequences in the genome (P. Johnson, unpubl.). These findings prompted us to initiate a search for novel C/EBP-related genes by screening genomic DNA libraries with a C/EBP gene probe. We report here the isolation and characterization of three such genes, designated crp1, crp2 [recently reported by other groups as NF-IL6 (Akira et al. 1990), LAP (Descombes et al. 1990), IL-6DBP (Poli et al. 1990) and AGP/EBP (Chang et al. 1990)], and crp3. We demonstrate that, together with C/EBP, the proteins encoded by these genes constitute a family of transcriptional activators with very similar DNA recognition properties and leucine zipper dimerization specificities.

\section{Results}

\section{Isolation of genes encoding C/EBP-related proteins}

Two EcoRI fragments that hybridized to a C/EBP DNAbinding domain probe were cloned from a rat genomic DNA phage library. The regions homologous to C/EBP within these 5.4- and 5.0-kb fragments were localized and sequenced. The cross-hybridizing segments of both fragments were found to be part of long protein-coding sequences (Fig. 1). The carboxy-terminal regions of the open reading frames display considerable amino acid sequence similarity to the C/EBP DNA-binding domain (Fig. 1) and exhibit structural hallmarks that are common to all bZIP DNA-binding proteins. Specifically, each protein includes a region rich in positively charged amino acids (the basic region) juxtaposed to, and in specific register with, a helix-permissive segment containing a heptad repeat of leucine residues (the leucine zipper; Landschulz et al. 1988a). These features strongly imply that both genes encode C/EBP-like bZIP proteins, which were therefore designated CRP1 and CRP2 (for C/EBP-related proteins 1 and 2).

A second round of hybridization screening was performed in which the basic regions of the $c / e b p, c r p 1$, and crp2 genes were used to probe a mouse genomic DNA library. One additional cross-hybridizing recombinant phage was identified in this search. DNA sequencing revealed that this clone also encodes a putative C/EBPrelated protein, which we designated CRP3. An amino acid sequence comparison of the four C/EBP-like proteins is presented in Figure 1. The proteins are most strikingly similar in their respective basic regions, where they share an identical 17-amino-acid segment that straddles the consensus bZIP basic motif (Kouzarides and Ziff 1988; Vinson et al. 1989). Significant homology is also evident in the leucine zipper domain, in which the sequences are $>70 \%$ homologous (including conservative substitutions). Elsewhere, the polypeptide sequences are quite divergent, except for a short region near the predicted amino terminus of each protein. This sequence corresponds to a domain in C/EBP that is apparently required for protein stability (Friedman and McKnight 1990; Pei and Shih 1991), and it may fulfill a similar role in CRP1, CRP2, and CRP3.

The sequence of the crp1 gene predicts at least one intron with two possible splice acceptor sites, both of which maintain the same translational reading frame. The inferred amino acid sequence presented in Figure 1 represents the joining of these two exons, wherein the underlined segment indicates sequences encoded by use of the first splice acceptor site. The present extent of the crp1 gene sequence does not indicate obvious transcriptional and translational start sites; therefore, the CRP1 sequence in Figure 1 contains an undefined amino terminus. A complete structural characterization of the crp1 gene has been hampered by our inability to detect CRP1 mRNA (see below). For reasons outlined in the Discussion, however, we are convinced that $c r p 1$ represents a functional gene. The crp2 genomic DNA sequence encodes a continuous open reading frame of 276 amino acids which, like C/EBP, is not interrupted by introns. A consensus TATAAA sequence is located 150 bp upstream of the initiator codon, and a consensus polyadenylation signal (AATAAA) is situated 460 bp downstream of the termination codon (data not shown). The positions of these two sequences predict a CRP2 transcript of $\sim 1.6 \mathrm{~kb}$, which has been confirmed by Northern analysis (data not shown; Chang et al. 1990; Descombes et al. 1990; Poli et al. 1990|. The crp3 gene likewise appears to lack introns and codes for a polypeptide of 268 amino acids. A variant of the TATA consensus (TAGAAAA) is located 65 bp upstream of an initiator codon, whereas the position of the polyadenylation signal has not yet been determined.

\section{Expression patterns of CRP family members}

We examined the expression patterns of CRP mRNAs in various mouse tissues by Northern blotting. We also used antisera directed against peptides from CRP1 and CRP2 to determine the tissue distributions of these two proteins by Western blot analysis of nuclear protein preparations. The results of all of these experiments, as well as the tissue distributions of C/EBP mRNA and pro- 


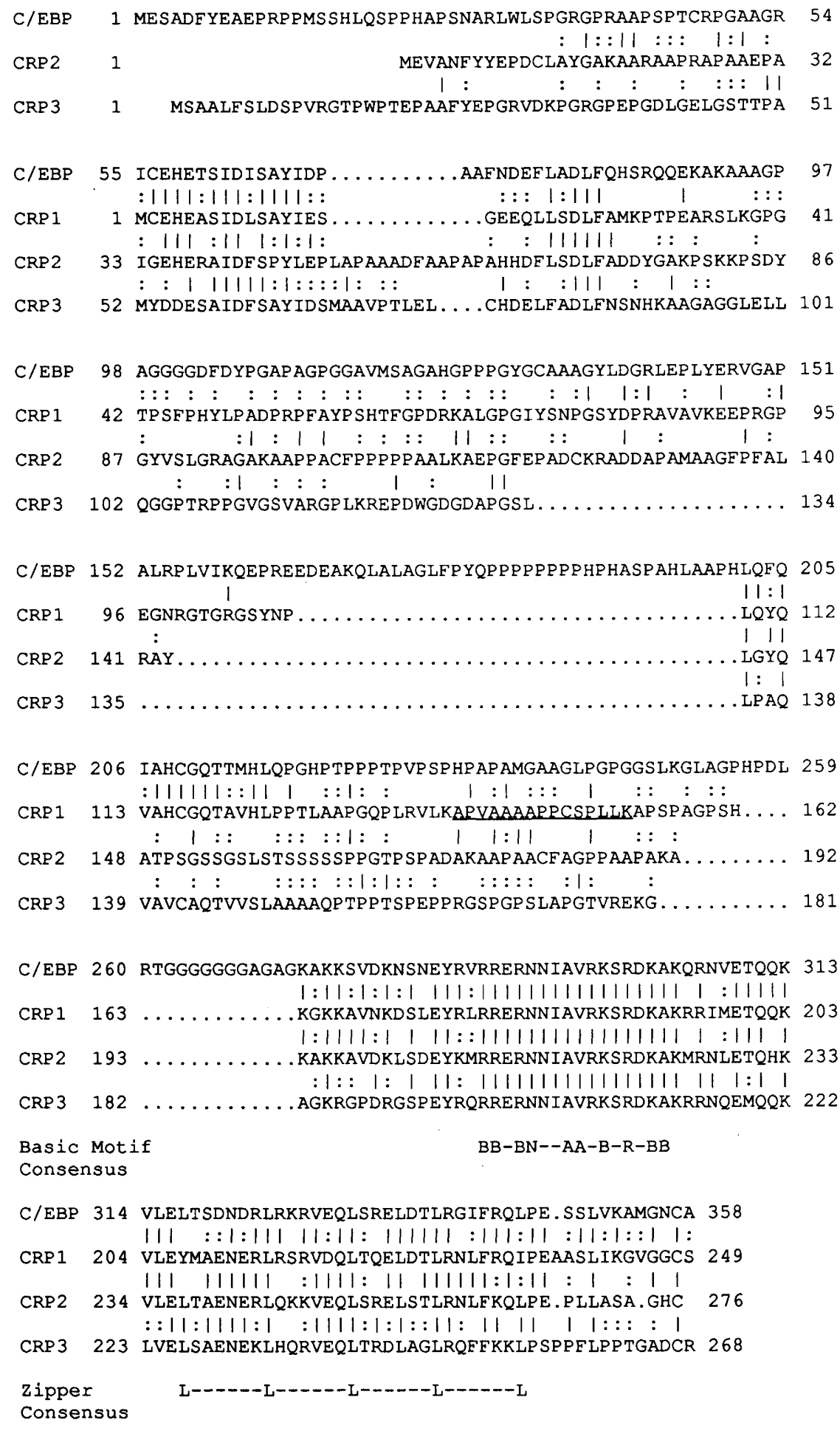
s 
Table 1. Tissue distribution of CRP mRNAs and proteins

\begin{tabular}{|c|c|c|c|c|c|c|c|c|}
\hline & \multicolumn{2}{|c|}{ C/EBP } & \multicolumn{2}{|c|}{ CRP2 } & \multicolumn{2}{|c|}{ CRP3 } & \multicolumn{2}{|c|}{ CRP1 } \\
\hline & RNA & protein & RNA & protein & RNA & protein & RNA & protein \\
\hline Liver & $++t$ & +++ & +++ & +++ & + & ND & - & - \\
\hline Lung & ++ & $+/ ?$ & ++ & ++ & +++ & ND & - & - \\
\hline Kidney & ++ & - & ++ & - & ++ & ND & - & - \\
\hline Adipose & ++ & + & + & ND & ++ & ND & - & ND \\
\hline Brain & + & - & + & - & + & ND & - & - \\
\hline Heart & + & - & + & - & + & ND & - & - \\
\hline Spleen & + & - & + & - & ++ & ND & - & - \\
\hline Testes & + & - & ++ & - & & & ND & - \\
\hline Uterus & & & & & + & ND & - & ND \\
\hline Ovary & & & ++ & ND & & & - & ND \\
\hline Stomach & & & + & ND & & & - & ND \\
\hline L. int. & & & + & ND & & & - & ND \\
\hline S. int. & + & ND & + & ND & & & - & ND \\
\hline Thymus & & & + & ND & & & - & ND \\
\hline Submax. & & & & & + & ND & - & ND \\
\hline Sk. mus. & + & ND & + & ND & & & - & ND \\
\hline
\end{tabular}

Abbreviations: (L. int.) Large intestine; (S. int.) small intestine; (Submax.) submaxillary gland; (Sk. mus.) skeletal muscle; (ND) not determined.

Data derived from Northern and Western blotting experiments to measure expression from c/ebp and crp genes is summarized. The approximate relative levels of expression are indicated by + symbols. A portion of the C/EBP expression data is taken from other studies (Birkenmeyer et al. 1989; W. Landschulz, P. Johnson, and S. McKnight, unpubl.).

examined. CRP2 mRNA was most abundant in liver, lung, kidney, testes, and ovary tissues but was detectable at varying levels in all cells examined. Conversely, CRP2 protein expression was found to be much more restricted. The $32-\mathrm{kD}$ CRP2 polypeptide was detected in liver and lung but not in brain, kidney, testes, and heart. CRP2 protein is thus expressed in only a subset of the tissues that contain CRP2 mRNA, suggesting a posttranscriptional component to its regulation. In this respect, as well as in its preferential accumulation in hepatocytes, CRP2 expression is quite similar to that of C/EBP. CRP3 transcripts were most abundant in the lung but were also present at appreciable levels in kidney, adipose, and spleen. At present, we have not obtained an antiserum specific for the CRP3 polypeptide; therefore, its cell type distribution has not yet been established.

\section{DNA-binding properties}

As mentioned above, the relatedness among C/EBP, CRP1, CRP2, and CRP3 is most pronounced in the basic region, where an invariant segment of 17 amino acids occurs (Fig. 1). Because the basic region of bZIP proteins has been shown to confer DNA sequence selectivity (Agre et al. 1989; Gemtz et al. 1989; Kouzarides and Ziff 1989; Sellers and Struhl 1989; Turner and Tjian 1989), the presence of strong sequence conservation within this part of the polypeptide suggested that all four proteins might bind DNA with similar, or identical, specificities. To test this prediction, hybrid proteins were constructed that contained amino acids 1-214 from the yeast GCN4 protein fused to equivalent DNA-binding domain segments from each CRP polypeptide. GCN4 hybrids were employed because they produce consistently high yields of protein in bacteria with the T7 expression system of Studier (Agre et al. 1989; Studier et al. 1990). Following expression, protein extracts were prepared and tested for DNA-binding activity in DNase I footprint assays (Galas and Schmitz 1978). Three different C/EBP-binding sites were employed: two within a fragment of the hepatitis B virus (HBV) enhancer (Landschulz et al. 1988b), and a third in the albumin gene promoter [the distal element I (DEI) (Cereghini et al. 1987) or D (Lichsteiner et al. 1987) site]. The footprint titration experiments of Figure 2 demonstrate that C/EBP, CRP1, and CRP2 generate nearly identical DNase I protection patterns on these probes. CRP3 also produced the same protected sequences (data not shown). The slight differences observed at the footprint boundaries are probably a consequence of the more divergent sequences flanking the actual DNA-contacting regions in each protein. Nonetheless, these results clearly demonstrate that C/EBP, CRP1, CRP2, and CRP3 comprise a functionally homologous DNA-binding protein family.

\section{Dimerization specificities}

As indicated previously, sequence similarities among the CRP polypeptides extend to the leucine zipper domains. Figure 3 depicts the four leucine zipper sequences on schematic $\alpha$-helices. A comparison shows that nearly every leucine zipper position contains either an identical or a conserved amino acid. In particular, helix "spokes" $1,2,4$, and 5 are highly similar. These are the positions most closely opposed in a coiled-coil protein dimer and are therefore likely to determine the specificity and affinity of protein-protein interactions. Their conserved 


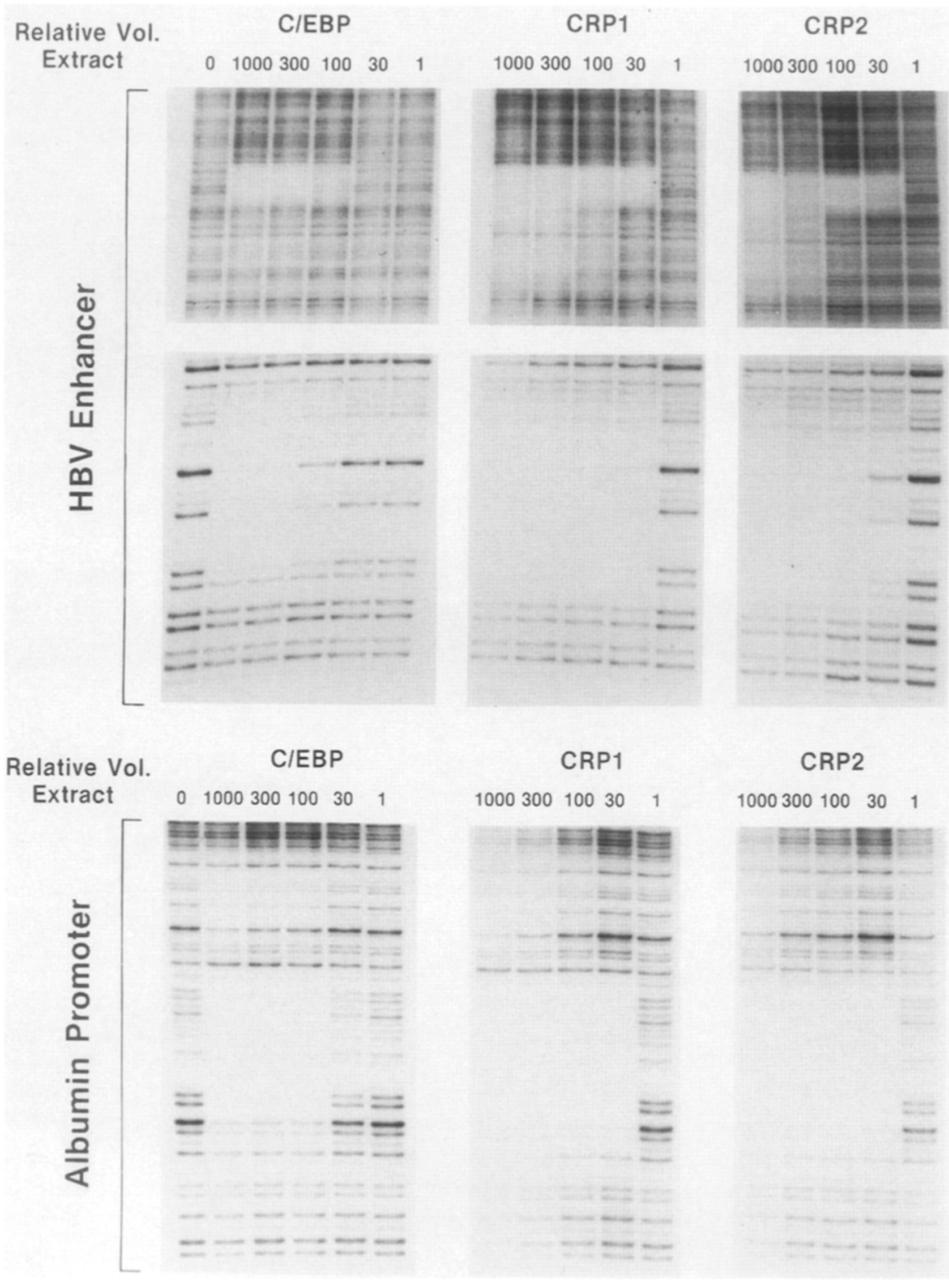

Figure 2. DNA-binding specificities of $\mathrm{C} / \mathrm{EBP}, \mathrm{CRP1}$, and CRP2. Fusion proteins carrying the putative DNA-binding regions of C/EBP, CRP1, and CRP2 were constructed and expressed in bacteria. Sequence-specific DNA-binding activities of the bacterially expressed proteins were analyzed by DNase I protection. End-labeled DNA fragments from either the HBV enhancer or the albumin gene promoter were used as probes. The apparent increased activity of CRP1 compared to C/EBP and CRP2 in these experiments is due to a greater amount of CRP1 protein in the extract and does not reflect an intrinsically higher affinity for the binding sites. nature suggested that the CRP polypeptides might be capable of dimer interactions between family members.

To test the dimerization potential of monomer CRP subunits, we developed a novel assay for dimer formation. The existence of C/EBP dimers was demonstrated previously by chemical cross-linking, with SDS-PAGE used to identify the resultant covalent dimers (Landschulz et al. 1989). C/EBP subunits in solution exchange very rapidly as measured by glutaraldehyde cross-linking; equilibrium between two electrophoretically distinguishable forms is achieved within minutes after mixing (Landschulz et al. 1989). C. Vinson and S. McKnight (pers. comm.) observed that the subunit exchange rate is inhibited drastically when reducing agents such as dithiothreitol (DTT) are omitted from the reaction. They proposed that the inhibitory effect results from a disulfide linkage between paired zipper helices, formed through a cysteine residue located near the C/EBP carboxyl terminus. From the amino acid sequence comparisons de- picted in Figure 1, it is evident that the same cysteine is conserved in CRP1, CRP2, and CRP3, suggesting that disulfide-linked dimers may also form in these proteins. We therefore employed a nonreducing SDS-PAGE assay, first to determine whether covalent C/EBP dimers could be directly detected by this method and subsequently to assess the abilities of the other CRP proteins to undergo homoand heterodimeric leucine zipper associations.

The bacterially produced C/EBP fusion protein described above $(\mathrm{G}: \mathrm{C} / \mathrm{EBP})$ was extracted and partially purified in the absence of reducing agents and then subjected to nonreducing SDS-PAGE (Fig. 4A). Under these conditions, a large proportion of the protein migrated at the position expected for a dimeric species. However, incubation with increasing amounts of DTT prior to electrophoresis caused its progressive conversion to the monomeric form (Fig. 4A). CRP1, CRP2, and CRP3 are likewise capable of forming disulfide-linked dimers (see below, and Fig. 4C). In all cases, it is clear that the oxi- 

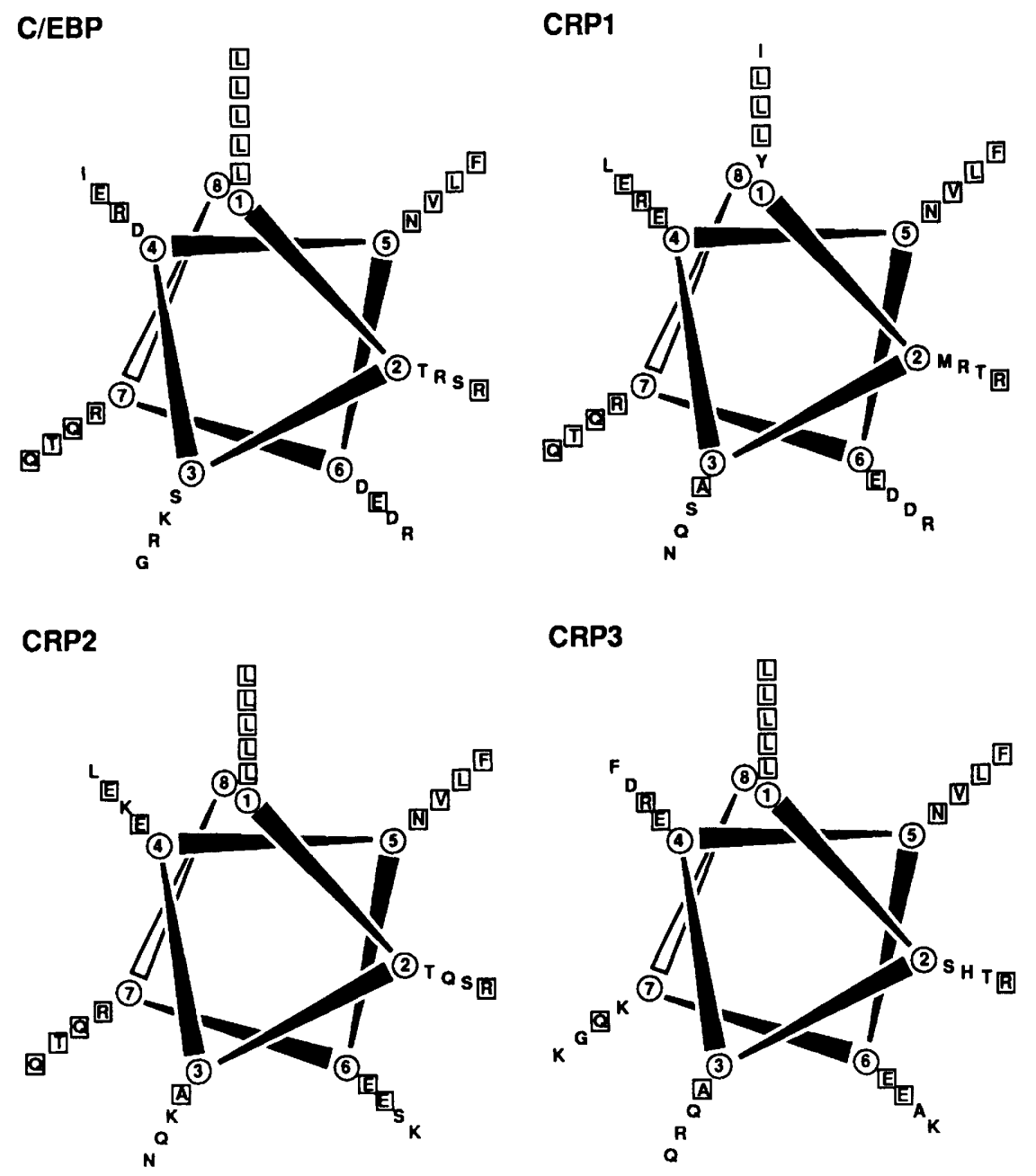

Figure 3. C/EBP, CRP1, CRP2, and CRP3 exhibit related leucine zipper domains. The leucine zipper domains of the four proteins are displayed as idealized $\alpha$-helices on helical wheels. Amino acids that are shared by at least three of the proteins are boxed.

dized dimers are joined via a cysteine residue at the carboxyl terminus, as this is the sole cysteine present in each of the fusion proteins. We refer to these covalently attached polypeptide species as linked dimers.

A variation of this assay was developed that allows mixing and reassortment of dimer subunits. A truncated C/EBP fusion gene (trG: C/EBP, which contains less of the GCN4 leader sequence) was constructed and expressed in Escherichia coli. $\operatorname{trG}: \mathrm{C} / \mathrm{EBP}$ was mixed in equimolar amounts with full-length $\mathrm{G}: \mathrm{C} / \mathrm{EBP}$, and the mixture was incubated at $37^{\circ} \mathrm{C}$ in the presence of a very low concentration of DTT $(0.05 \mathrm{~mm})$ to promote transient reduction of the covalently linked dimers. At various times, aliquots were analyzed on nonreducing protein gels (Fig. 4B). A slow conversion to monomers was observed, with reduction nearly complete by $4 \mathrm{hr}$. After $24 \mathrm{hr}$, however, most of the monomeric protein had been converted again to dimers, coincident with the appearance of an intermediate heterodimer band. The dimeric products were present in the ratios expected for equilibrium mixtures $(1: 2: 1)$, suggesting that complete subunit reassortment had occurred. We infer that a low level of reducing agent causes cleavage of the linked dimer and allows subsequent subunit exchange but that the even- tual depletion of reduced DTT in the system allows cysteine reoxidation to take place.

The experiments presented thus far have not addressed the specificity of linked dimer formation. In particular, it is conceivable that the disulfide bond between subunits occurs as a consequence of nonspecific protein aggregation rather than from leucine zipper interactions. This possibility was examined by testing whether the appearance of a covalent heterodimer is dependent on the presence of a functional leucine zipper. A truncated C/EBP fusion protein was constructed that contained leucineto-valine substitutions at the first two leucines in the zipper $\left(\operatorname{tr} G: \mathrm{L}_{12} \mathrm{~V}\right)$. C/EBP carrying the $\mathrm{L}_{12} \mathrm{~V}$ mutation dimerizes very inefficiently as judged by the standard chemical cross-linking assay (Landschulz et al. 1989). $\operatorname{trG}: \mathrm{L}_{12} \mathrm{~V}$ was combined with the full-length $\mathrm{G}: \mathrm{C} / \mathrm{EBP}$ polypeptide, and the mixture was subjected to the low DTT dimerization regimen described above (Fig. 4B). A small proportion of $\operatorname{tr} G: \mathrm{L}_{12} \mathrm{~V}$ protein is covalently dimeric in the starting extract, probably because over time, the disulfide link traps even transient leucine zipper associations. More importantly, however, no trG : $\mathrm{L}_{12} \mathrm{~V}$ homo- or heterodimers were generated in the subunit exchange reaction, whereas reoxidation of the 

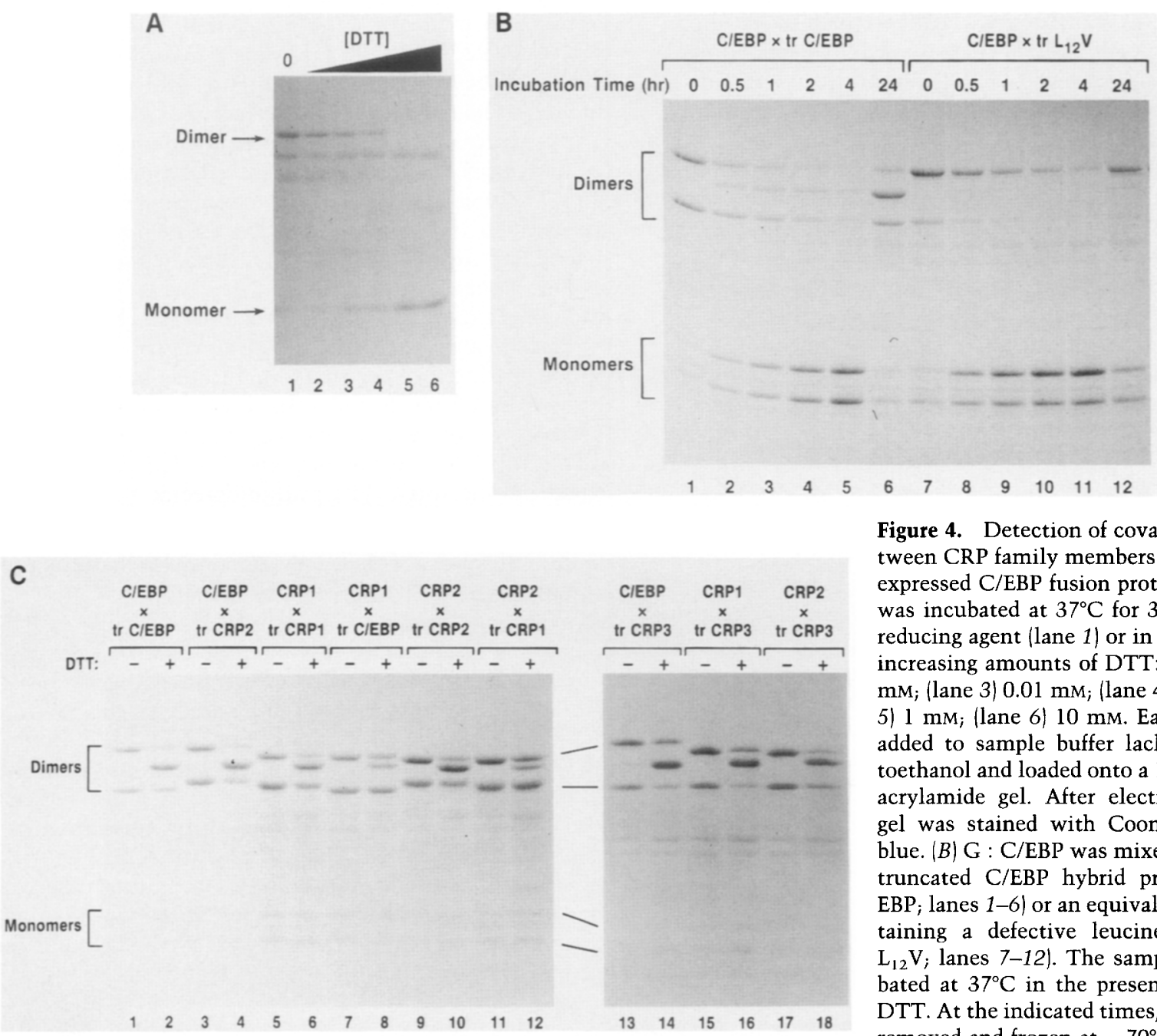

Figure 4. Detection of covalent dimers between CRP family members. (A) Bacterially expressed C/EBP fusion protein (G: C/EBP) was incubated at $37^{\circ} \mathrm{C}$ for $30 \mathrm{~min}$ without reducing agent (lane 1 ) or in the presence of increasing amounts of DTT: (Lane 2) 0.001

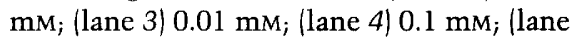
5) $1 \mathrm{~mm}$; (lane 6) $10 \mathrm{~mm}$. Each sample was added to sample buffer lacking $\beta$-mercaptoethanol and loaded onto a $10 \%$ SDS-polyacrylamide gel. After electrophoresis, the gel was stained with Coomassie brilliant blue. $(B) \mathrm{G}: \mathrm{C} / \mathrm{EBP}$ was mixed with either a truncated C/EBP hybrid protein (trG:C/ $\mathrm{EBP}$; lanes 1-6) or an equivalent hybrid containing a defective leucine zipper (trG : $\mathrm{L}_{12} \mathrm{~V}$; lanes 7-12). The samples were incubated at $37^{\circ} \mathrm{C}$ in the presence of $0.05 \mathrm{~mm}$ DTT. At the indicated times, an aliquot was removed and frozen at $-70^{\circ} \mathrm{C}$ and the samples were subsequently analyzed by nonreducing SDS-PAGE. $(C)$ Pairs of full-length and truncated hybrid proteins were mixed and incubated for $24 \mathrm{hr}$ at $37^{\circ} \mathrm{C}$ in the absence (odd-numbered lanes) or presence (even-numbered lanes) of $0.05 \mathrm{~mm}$ DTT. Samples were analyzed by nonreducing SDS-PAGE.

full-length unaltered subunit occurred efficiently. These results demonstrate that linked dimer formation is dependent on (and therefore reflects) leucine zipper associations and can be used to assess interactions between all CRP polypeptides.

To test the possibility that C/EBP, CRP1, CRP2, and CRP3 can associate in heterodimeric combinations, we engineered truncated versions of all four fusion proteins. Pairs of electrophoretically distinguishable proteins were then mixed and incubated for $24 \mathrm{hr}$ either in the absence or in the presence of $0.05 \mathrm{mM}$ DTT, followed by nonreducing SDS-PAGE (Fig. 4C). When full-length and truncated versions of the same protein were coincubated without DTT, only the parental dimer bands were apparent, whereas the inclusion of DTT resulted in an approximate $1: 2: 1$ ratio of dimeric forms. Next, we examined heterodimer formation between full-length and truncated forms of different proteins. In all combinations among C/EBP, CRP2, and CRP3, the heterodimer again represented one-half of all dimer forms after $24 \mathrm{hr}$ (Fig.
$4 \mathrm{C}$, lanes $4,14,18$ ), indicating that self-dimerization and heterodimerization could occur with equal efficiency. However, when CRP1 was mixed with either C/EBP or CRP2, the heterodimer was under-represented at equilibrium (lanes 8, 12). The opposite combinations of fulllength and truncated polypeptides in the CRP1 mixtures did not alter the results, nor did further incubation at $37^{\circ} \mathrm{C}$ affect the dimer ratio (data not shown). Thus, although CRPl can dimerize efficiently with both itself and CRP3 (lanes 6 and 16), its interactions with CRP2 and C/EBP are apparently less avid.

Because linked dimer associations require both leucine zipper docking and disulfide bond formation, it was possible that the second step and not the first is inefficient in the assembly of CRP1 : C/EBP and CRP1 : CRP2 heterodimers. Therefore, we also carried out gel retardation heterodimerization assays (Hope and Struhl 1987) in which the binding reactions could be performed under reducing conditions. Pairs of electrophoretically distinct fusion proteins were mixed in the presence of $5 \mathrm{~mm}$ DTT 
and allowed to equilibrate. The mixtures were then added to binding reactions containing a labeled albumin DEI site oligonucleotide, and the products were separated by gel electrophoresis (Fig. 5). In every combination, a band of intermediate mobility appeared, indicating the presence of a heterodimeric complex. In accordance with the previous assays, self-dimers and crossdimers gave equivalent distributions of complexes except for those involving CRP1 with C/EBP or CRP2 (lanes 5 and 6). In these cases, the heterodimeric species were again reduced in intensity, demonstrating that the CRP1 leucine zipper has an intrinsically lower affinity for C/EBP and CRP2 in coiled-coil interactions. This property almost certainly explains the similar heterodimer decrease observed in the covalent dimerization assays.

\section{$C / E B P$ : CRP2 heterodimers form in vivo}

The observations that C/EBP and CRP2 subunits interact in vitro and are apparently coexpressed in hepatocytes raises the possibility that such complexes can occur intracellularly. We addressed this question by performing immunoprecipitation experiments using cells cotransfected with and transiently expressing the $c / e b p$ and $c r p 2$ genes. Transfection was necessary because proliferating cells synthesize little or no endogenous C/EBP

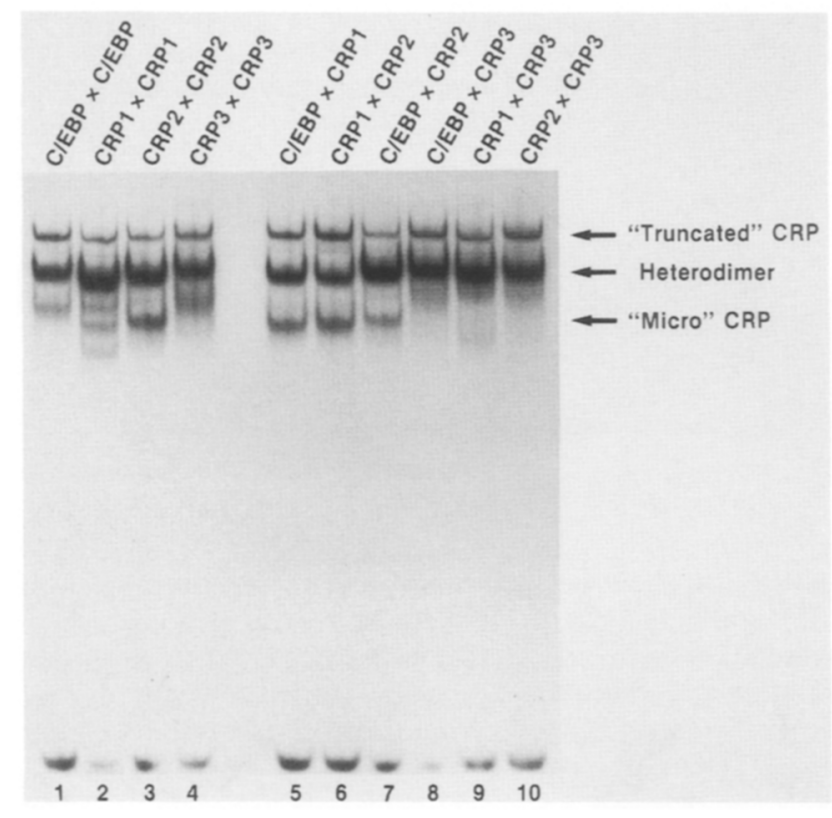

Figure 5. Detection of dimers between CRP family members by gel retardation assays. Pairs of truncated and micro forms of each CRP protein (see text) were mixed in the presence of $5 \mathrm{~mm}$ DTT for $30 \mathrm{~min}$ at $37^{\circ} \mathrm{C}$. The first protein in each lane caption indicates the truncated form and the second indicates the micro form. Each mixture was then incubated for $20 \mathrm{~min}$ on ice with a labeled, double-stranded oligonucleotide containing the albumin DEI sequence (Cereghini et al. 1987). The complexes were separated by electrophoresis on nondenaturing polyacrylamide gels and visualized by autoradiography. $\mu$ CRP3 (lanes $8-10$ ) migrates as a diffuse band. protein (Friedman et al. 1989; Umek et al. 1991), although CRP2 is expressed in some cell lines (Akira et al. 1990; Poli et al. 1990; S.C. Williams and P.F. Johnson, unpubl.). HeLa cells were transfected with C/EBP and CRP2 expression plasmids, either individually or in combination, and the cells were subsequently labeled with $\left[{ }^{35} S\right]$ methionine. Protein extracts were prepared and used in immunoprecipitation assays with antisera specific for either C/EBP or CRP2. Labeled polypeptides of the expected molecular weights were precipitated from singly transfected cell extracts when the appropriate cognate antiserum was added (Fig. 6, lanes 5, 9), thus demonstrating the specificity of antibody binding. In extracts from cotransfected cells, both proteins were observed in immune complexes containing either anti-C/ EBP or anti-CRP2 antibodies (Fig. 6F). This is especially evident in the anti-C/EBP immunoprecipitations, where CRP2 is clearly visible (lane 17). In the reciprocal experiment, C/EBP was similarly detected in the material precipitated by the CRP2 antibody (lane 18).

These experiments demonstrate that C/EBP : CRP2 complexes, presumably dimers, assemble in cells that express both proteins. To show that these dimers exist in vivo and are not formed after preparation of the cell-free extracts, mixing experiments were performed. Cells singly transfected with each expression plasmid were labeled and then mixed, either prior to or following cell lysis. The colysis and postlysis mixtures were then immunoprecipitated with the C/EBP- and CRP2-specific antiserum (Fig. 6E,D, respectively). In neither case was coprecipitation of C/EBP and CRP2 observed, demonstrating that the complexes detected by this assay must occur within the cell, prior to cell lysis.

\section{CRP2 activates a target promoter preferentially in hepatic cells}

By analogy to C/EBP, we anticipated that the other CRP family proteins would function as transcriptional activators. We compared the abilities of CRP2 and C/EBP to stimulate transcription of a cotransfected reporter gene (CAT) fused to the mouse albumin promoter. In previous experiments, C/EBP enhanced albumin transcription at least 50-fold in a human hepatoma cell line (HepG2) but caused only a modest stimulation in L fibroblasts (Friedman et al. 1989). We used the C/EBP and CRP2 expression plasmids described above, together with pAlbCAT, to transfect either HepG2 or HeLa cells. CAT activities were measured and normalized to that of pAlbCAT alone. The results with the use of increasing amounts of the effector plasmid are presented in Figure 7. The two proteins are capable of stimulating the albumin promoter 35- to 40-fold in HepG2 cells, with expression peaking at $\sim 2.5 \mu \mathrm{g}$ of effector plasmid. Similar input DNA optima were obtained in HeLa cell transfections; however, in this case, the maximal enhancement of pAlbCAT by C/EBP was only 6.5 -fold, and by CRP $2,2.5$ fold. This recipient cell type effect is not explained by reduced synthesis of the trans-activator proteins in HeLa cells, as expression of C/EBP and CRP2 in HeLa cells is 


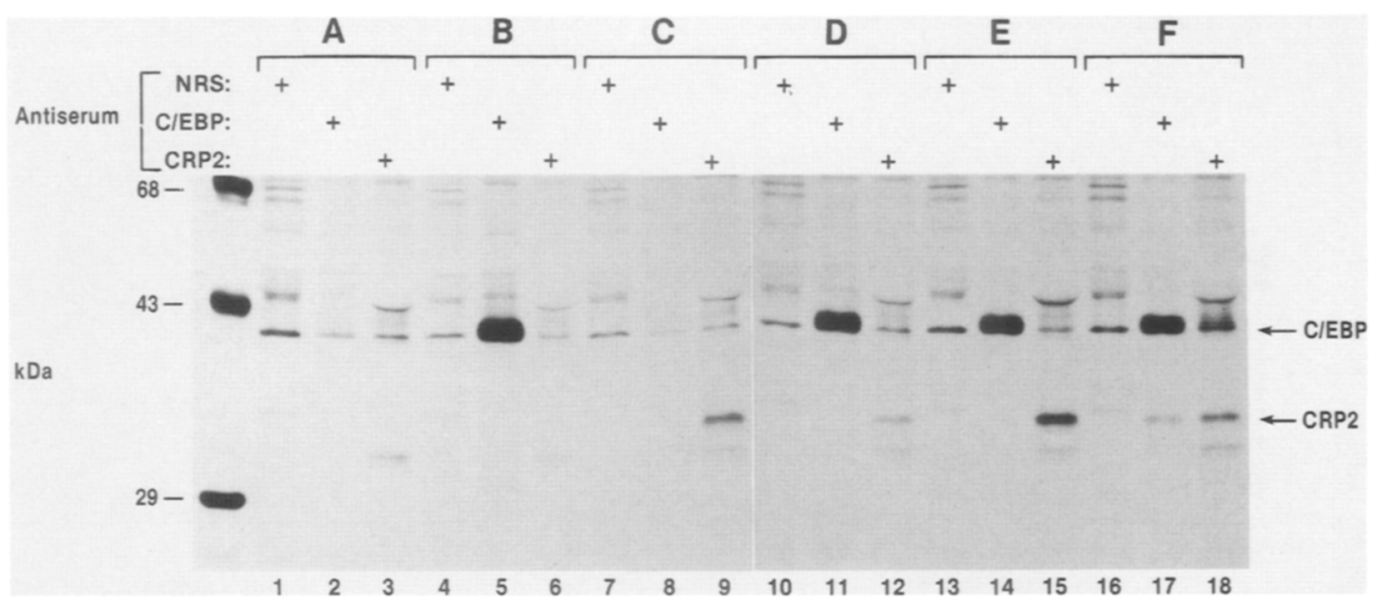

Figure 6. $\mathrm{C} / \mathrm{EBP}$ and CRP2 form heterodimers in vivo. HeLa cells were transfected with either no DNA $(A)$, pMEXC/EBP or pMEXCRP2 individually $(B-E)$, or pMEXC/EBP and pMEXCRP2 together $(F)$; the cells were labeled with $\left[{ }^{35} S\right]$ methionine. Cell lysates were prepared and immunoprecipitated with each of the three indicated antisera. $(B, C)$ Immunoprecipitates of cells transfected individually with the C/EBP and CRP2 expression plasmids, respectively. $(D)$ Immunoprecipitation with a mixture of extracts from cells transfected individually (postlysis mix). (E) Immunoprecipitate from cells that were transfected individually but combined prior to lysis (colysis mix). (F) Cells were cotransfected with both plasmids. (NRS) Normal (nonimmune) rabbit serum.

nearly fivefold greater than in HepG2 cells, as judged by Western blots (Fig. 7B). (This discrepancy probably reflects the proportion of transfected cells in the two cell lines rather than a fivefold difference in the amount of expressed protein per transfected cell.)

Both C/EBP and CRP2 are thus $\sim 10$ times more potent as trans-activators in HepG2 cells than in HeLa cells. Differences of a comparable magnitude are observed when an artificial promoter composed only of the albumin DEI and TATA elements is used to drive the CAT gene (data not shown). This result demonstrates that the differential activity is not caused by interactions with cell-specific factors bound at neighboring sites within the albumin promoter. Rather, the difference probably results from a function that acts more directly to modify or augment the DNA-binding or activation properties of $\mathrm{C} / \mathrm{EBP}$ and CRP2.

Finally, we tested whether C/EBP and CRP2 can synergistically activate transcription from the albumin promoter, a possibility suggested by their ability to heterodimerize in vivo. Figure $7 \mathrm{C}$ shows the results of a trans-activation experiment in HepG2 cells where the two effectors were used either individually or in combination. Transfecting the two effector plasmids together did not increase or decrease pAlbCAT activity by a statistically significant magnitude compared to each transactivator alone. This implies that a C/EBP : CRP2 heterodimer has approximately the same transcriptional activation potential as either homodimer, at least in the context of binding to the DEI/D site in the albumin promoter.

\section{Discussion}

Our studies identify three genes (crp1, crp2, and crp3) that encode proteins whose DNA-binding and dimeriza- tion properties are homologous to those of the transcriptional activator C/EBP and that therefore define a distinct bZIP protein subfamily. The four C/EBP-like proteins are specified by unlinked genes that map to separate mouse chromosomes. c/ebp was localized previously to chromosome 7 (Birkenmeier et al. 1989), whereas crp1, crp2, and crp3 reside on chromosomes 14, 2 , and 16, respectively (N. Jenkins and N. Copeland, pers. comm.). Preliminary Southern blot experiments with rat and mouse DNAs hybridized at low stringency with CRP basic region probes indicate the existence of 5-10 additional, weakly homologous sequences in the mammalian genome (C.A. Cantwell, M. Chamberlin, and P.F. Johnson, unpubl.). The CRP family may therefore be much more extensive than is suggested by its current composition, and the isolation of new members by crosshybridization may be relatively straightforward. Recently, Roman et al. (1990) reported the isolation of a cDNA clone encoding a polypeptide (Ig/EBP-1) that-although its basic region sequence is somewhat diverged from the perfectly conserved CRP basic domain-also exhibits C/EBP-like DNA-binding and dimerization properties. Thus, a total of five C/EBP-related proteins have now been firmly identified.

On the basis of their restricted expression patterns, we postulate that the CRP proteins function to regulate cell type-specific transcription of subordinate sets of genes. We have not currently identified a cell type in which the crp1 gene is expressed. However, for the following reasons we infer that $\operatorname{crp} 1$ represents a functional gene and not a pseudogene: (1) It contains a putative intron that, when theoretically spliced, yields a long open reading frame with amino acid sequence similarities to the amino- and carboxy-terminal domains that are conserved throughout the CRP family (Fig. 1); (2) 7 of the 17 codons in the CRPI basic region carry conservative third 
A
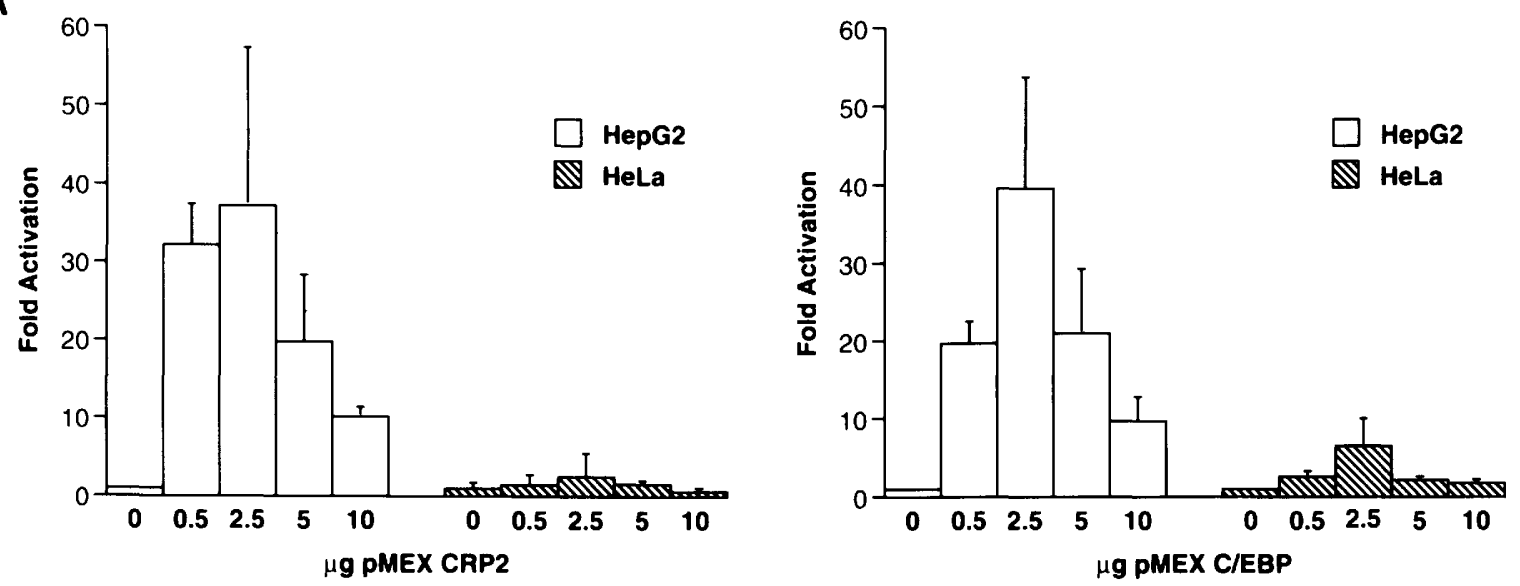

B
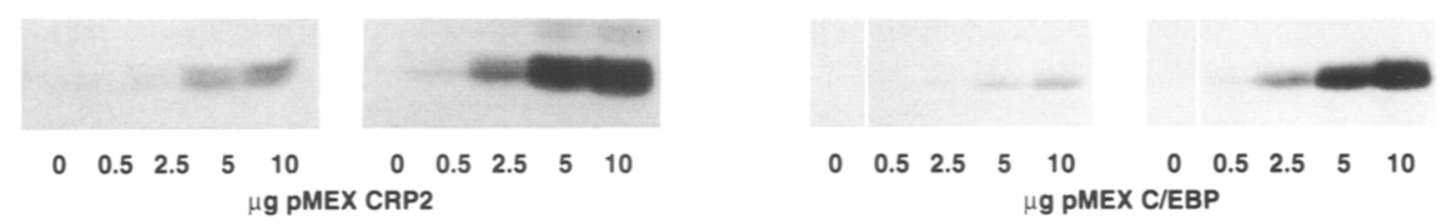

Figure 7. Transcriptional activation by C/EBP and CRP2. (A) Trans-activation of the albumin promoter by CRP2 and C/EBP in HepG 2 and HeLa cells. Different amounts of the effector plasmids were cotransfected with a constant amount of the reporter construct into either cell type. CAT activity was measured and is expressed graphically as the fold activation (士S.D.) relative to the CAT activity directed by the reporter plasmid alone. Each point represents the average of at least three independent experiments. $(B)$ Western analysis of CRP2 and C/EBP expression in HepG2 and HeLa cells. Cell pellets (crude nuclei) from CAT assays were solubilized in protein gel sample buffer and analyzed by Western blotting. Identical gels were probed with antisera directed against either C/EBP or CRP2. (C) Co-trans-activation of the albumin promoter by CRP2 and C/EBP in HepG2 cells. CRP2 and C/EBP expression plasmids, either individually or in combination, were transfected together with pAlbCAT into HepG 2 cells, and CAT activities were measured. The activation ratio (normalized to pAlbCAT alone) is shown, averaged for three experiments.

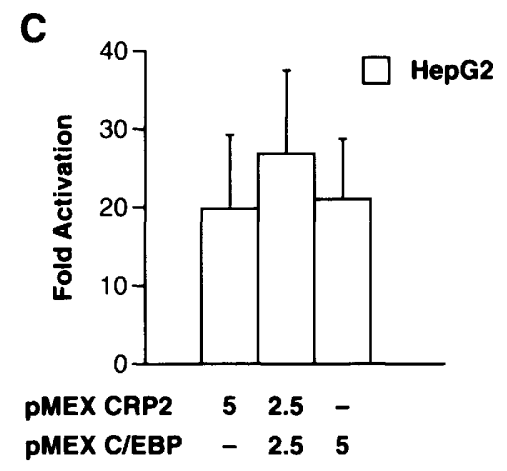

position mutations when compared to the $c / e b p$ DNA sequence, suggesting a strong selective pressure to maintain function; (3) protein products expressed from the crp1 gene are functional, both in binding DNA (Fig. 2) and in activating transcription of a reporter gene in cotransfection experiments (S.C. Williams and P.F. Johnson, unpubl.); and (4) the crp1 genes from rat and mouse are highly similar (data not shown). In some respects, CRP1 seems to be a more divergent member of the CRP family. In addition to the obvious differences in expression patterns, crp1 contains at least one intron, whereas the other three genes are unspliced. Furthermore, CRP1 heterodimerizes less efficiently with C/EBP and CRP2 (although it makes strong associations with CRP3), whereas C/EBP, CRP2, and CRP3 comprise a group with internally equivalent dimerization specificities.

C/EBP, CRP2, and CRP3 are expressed in tissue-restricted patterns that are partially overlapping. The C/EBP polypeptide was shown previously to be present in differentiated hepatocytes and adipocytes (Birken- meier et al. 1989; Friedman et al. 1989) and is probably also expressed in the lung (P.F. Johnson and P. Donovan, unpubl.). CRP2 was detected immunologically in liver (Table 1; Descombes et al. 1990) and in lung (Descombes et al. 1990; S.C. Williams and P.F. Johnson, unpubl.). Because CRP3 mRNA was found in greatest abundance in lung and is also present in liver (Table 1), these two tissues represent potential common sites of expression for all three proteins (although we have not yet generated antisera to confirm the presence of the CRP3 polypeptide in these cell types). If so, adult hepatocyte nuclei accommodate a minimum of five distinct factors with binding specificity to the albumin DEI/D element. This accounting includes Ig/EBP-1 (Roman et al. 1990) and DBP, a liver-enriched protein that can also elevate albumin gene transcription by virtue of binding to the DEI/D site (Mueller et al. 1990). DBP has recently been identified as a member of the bZIP structural family (Iyer et al. 1991) but is not capable of making heterospecific dimers with C/EBP (Mueller et al. 1990) and, by extrapolation, is also not anticipated to dimerize with the C/EBP-related 
proteins. In principle, then, the number of different dimeric protein species in hepatocytes that exhibit C/EBP-like DNA recognition properties is quite large. Why liver cells require this many apparently redundant DNA-binding factors and to what degree each protein contributes to the regulation of liver genes containing C/EBP-binding sites (such as the albumin gene) are questions for future investigations.

During the course of these studies, four groups independently reported the cloning of CRP2 cDNAs from human (NF-IL6; Akira et al. 1990), rat [LAP (Descombes et al. 1990) and IL-6DBP (Poli et al. 1990)], and mouse (AGP/EBP; Chang et al. 1990) sources. LAP was isolated in a search for liver-specific cDNAs encoding albumin DEI/D site-binding proteins. The others were also cloned from expression libraries screened with the in situ DNAbinding method (Singh et al. 1988). However, these searches employed DNA ligands corresponding to IL-1 or IL-6 responsive elements (ILREs) from promoters controlling primarily liver-specific genes that are activated during the acute phase response. Because, in retrospect, acute phase ILREs are similar to the consensus C/EBPbinding site (Poli and Cortese 1989; Isshiki et al. 1990; Majello et al. 1990), the identification of a C/EBP-related protein binding to these elements is not unexpected. Apparently, then, one function for CRP2 is as a nuclear target for a signal transduction pathway that culminates in the up-regulation of genes responsive to Il-1 or Il-6 stimulation. Consistent with this role, CRP2 undergoes a post-translationally controlled increase in DNA-binding activity when cells are exposed to Il-1 or Il-6 (Akira et al. 1990; Poli et al. 1990) and is capable of enhancing transcription from promoters bearing ILREs or related sequences (Akira et al. 1990; Chang et al. 1990; Descombes et al. 1990; Poli et al. 1990).

The probable coordinate expression of C/EBP, CRP2, and CRP3 in cells of the lung and liver, along with their ability to dimerize in vitro, may reflect important cellular functions for heterodimers formed among these three polypeptides. The immunoprecipitation experiments presented in Figure 6 provide compelling evidence for the existence of C/EBP : CRP2 complexes in cells that are overexpressing the two subunits. It will be important to perform similar coimmunoprecipitation experiments with liver and lung tissue lysates to verify that the same heterodimeric species exists under actual physiological conditions. We also tested for evidence of functional interactions between C/EBP and CRP2 in trans-activation experiments but could detect no cooperation between C/EBP and CRP2 in stimulating expression from the albumin (and synthetic DEI) promoters (Fig. 7C and data not shown). However, because by themselves both proteins are potent activators of the albumin promoter, this finding cannot be construed as evidence disfavoring heterodimer formation. Poli et al. (1990) have measured a modest synergistic effect of IL-6DBP (CRP2) in combination with C/EBP in trans-activating a synthetic ILRE promoter but only when the recipient cells were treated with Il-6. This result implies the existence of a functional interaction between the two proteins in vivo, but the increased transcriptional activity of the heterodimer may depend on the Il-6-induced alteration of CRP2 activity referred to above.

One of the more intriguing features of the C/EBP-like proteins is their ability to form disulfide linkages between paired leucine zippers. These bonds can be made efficiently in vitro, because incubation in the absence of reducing agents resulted in nearly quantitative conversion to the covalent dimer form (Fig. 4). The specificity of such covalent associations is evidenced by the fact that in crude $E$. coli protein extracts, nearly $100 \%$ of the protein occurs as linked dimer and very little is randomly bound to other proteins. Furthermore, a recently discovered chicken bZIP protein, VBP (Iyer et al. 1991), also forms a covalent homodimeric structure, yet no covalent or noncovalent heterodimers between this protein and the CRP proteins could be observed (S.C. Williams, P.F. Johnson, S. Iyer, and J. Burch, unpubl.). Thus, covalent linkages are exquisitely dependent on the prior formation of coiled-coil interactions between leucine zipper helices.

In this study we used the ability of the CRP proteins to associate covalently as the sole method for assessing their leucine zipper dimerization specificities. Does covalent dimerization have any functional significance? We have not detected tangible differences between covalent and noncovalent dimers in binding to DNA. Nonetheless, it is conceivable that linked dimers are necessary for stabilizing subunit interactions in vivo or serve to maintain a homeostatic population of CRP dimers within the cell. Our present experiments have not addressed the issue of whether linked CRP dimers occur within the (generally) reducing environment of a cell (Gilbert 1984; Ziegler 1985). Future investigations will focus on this question and on whether covalent dimeric complexes, if present, are in any respect required for the regulatory functions executed by the C/EBP protein family.

\section{Materials and methods}

Enzymes and reagents

Restriction and modifying enzymes were purchased from Boehringer Mannheim Biochemicals, Bethesda Research Laboratories, New England Biolabs, Stratagene, Inc., and Promega, Inc. Polymerase chain reactions (PCRs) were performed with components supplied in the Gene Amp kit (Perkin-Elmer Cetus). Radioisotopes were purchased from Amersham, Inc., and New England Nuclear.

\section{Cloning and characterization of CRP1, CRP2, and CRP3}

All sequences were isolated from phage $\lambda$ libraries prepared from genomic rat (Sprague-Dawley) or mouse DNA. A rat partial EcoRI library was obtained from T. Sargent, and a mouse (B6/CBA hybrid) partial SauIIIA library (Stratagene) was a gift of M. Strobel. crp1 and crp2 were detected in recombinant phage $\lambda$ libraries with a 299-bp NaeI fragment containing the DNAbinding domain from the rat $c / e b p$ gene as a probe. Filters were washed under conditions of reduced stringency $\left(65^{\circ} \mathrm{C}, 0.2 \times\right.$ SSCP). CRP3 was detected in a mouse genomic DNA library by 
using a similar protocol except that duplicate phage lifts were probed independently with the basic regions of $c / e b p, c r p 1$, and crp2 $\left(55^{\circ} \mathrm{C} 1 \times \mathrm{SSC}\right)$. The region of probe homology for each recombinant phage was identified by standard subcloning methods and sequenced using either the Sequenase or Taquence sequencing kits (U.S. Biochemical). Sequence analysis was carried out by using programs from the University of Wisconsin Genetics Computer Group (Devereux et al. 1984).

\section{Expression of hybrid proteins in bacteria}

Three different size classes of GCN4-CRP hybrid expression plasmids were constructed, all of which contained a CRP DNAbinding domain fused to different amino-terminal segments of the yeast GCN4 gene. The full-length hybrid proteins $(\mathrm{G}: \mathrm{C} /$ EBP, G : CRP1, and G : CRP2) were generated according to the method of Yon and Fried (1989). This method uses a PCR procedure to join two sequences precisely, the fusion point being specified by a synthetic linker oligonucleotide. Full-length proteins carry amino acids $1-214$ of GCN4. Truncated hybrid proteins (designated $\operatorname{tr} G: \mathrm{C} / \mathrm{EBP}, \operatorname{tr} G: \mathrm{CRP}$, $\operatorname{tr} G: \mathrm{CRP} 2$, $\operatorname{tr} G: \mathrm{CRP} 3$, and $\operatorname{tr} G: \mathrm{L}_{12} \mathrm{~V}$ ) were constructed by first amplifying the DNA-binding domain of each CRP gene by the use of PCR. The 5 '-amplification primers carried $X b a I$ cloning sites so that each product could be inserted in-frame into an $\mathrm{XbaI}$ site at codon 177 of the GCN4 gene. A third set of plasmids encoding microhybrid proteins $/ \mu \mathrm{G}: \mathrm{C} / \mathrm{EBP}, \mu \mathrm{G}: \mathrm{CRP} 1, \mu \mathrm{G}: \mathrm{CRP} 2$, and $\mu \mathrm{G}: \mathrm{CRP} 3$ | were constructed in a similar way to the truncated constructs except that the cloning site used was a BamHI site at amino acid 35 of GCN4. The following CRP protein amino acid sequences were included in the hybrid proteins: C/EBP, 273358; CRP1, 162-249; CRP2, 192-276; CRP3, 181-268. The following combinations of PCR primers were employed to generate each hybrid gene: (G: C/EBP) GCN4 5', GCN4-C/EBP linker and C/EBP 3'; (G: CRPl) GCN4 5', GCN4-CRPl linker and CRP1 3'; (G: CRP2) GCN4 5', GCN4-CRP2 linker and CRP2 $3^{\prime} ;\left(t r G: \mathrm{C} / \mathrm{EBP}\right.$ and $\left.\operatorname{tr} G: \mathrm{L}_{12} \mathrm{~V}\right) \operatorname{tr} G: \mathrm{C} / \mathrm{EBP} 5^{\prime}$ and C/EBP $3^{\prime}$; $(\operatorname{tr} G$ : CRP1) trCRP1 5' and CRP1 3'; (trG: CRP2) trCRP2 5' and CRP2 $3^{\prime}$; $\left(\operatorname{tr} G:\right.$ CRP3) $\mu /$ trCRP3 $5^{\prime}$ and CRP3 $3^{\prime}$; $(\mu \mathrm{G}: \mathrm{C} /$ EBP) $\mu$ C/EBP $5{ }^{\prime}$ and C/EBP $3^{\prime}$; $\left(\mu \mathrm{G}:\right.$ : CRP1) $\mu$ CRP1 $5^{\prime}$ and CRP1 $3^{\prime}$; ( $\mu \mathrm{G}:$ CRP2) $\mu \mathrm{CRP} 25^{\prime}$ and CRP2 $3^{\prime}$; ( $\mu \mathrm{G}$ : CRP3) $\mu / \mathrm{trCRP} 3$ $5^{\prime}$ and CRP3 $3^{\prime}$. PCR conditions for generating full-length hybrids were denaturing at $92^{\circ} \mathrm{C}, 1 \mathrm{~min}$; annealing at $55^{\circ} \mathrm{C}, 2 \mathrm{~min}$; extension at $72^{\circ} \mathrm{C}, 3 \mathrm{~min}$, for 32 cycles. PCR conditions for generating truncated and micro constructs were denaturing at $92^{\circ} \mathrm{C}, 2 \mathrm{~min}$; annealing and extension at $55^{\circ} \mathrm{C}, 2 \mathrm{~min} ; 32$ cycles. Oligonucleotides used to generate GCN4-CRP hybrid genes were as follows:

GCN4 5', CCCACTCCTGTTCTAGAAGATGC; GCN4-C/ EBP linker, ATCCACCGACTTCTTGGCCTTGCCCGAACGCTGTTTGCGGTTGTAAGC; GCN4-CRP1 linker, TGCCTTCTTGCCCTTGTGCGAACGCTGTTTGCGGTT; GCN4-CRP2 linker, CGCCTTCTTGGCCTTGGCCGAACGCTGTTTGCGGTT; trC/EBP 5', GACGGCTCTAGAGGGCAAGGCCAAGAAG; trCRP1 5', GACGGCTCTAGAGCACAAGGGCAAGAAG; trCRP2 5', GACGGCTCTAGAGGCCAAGGCCAAGAAG; $\mu$ C/EBP 5 ', GACGGCGGATCCGGGCAAGGCCAAGAAG; $\mu$ CRP1 5 ', GACGGCGGATCCGCACAAGGGCAAGAAG; $\mu$ CRP2 5 ', GACGGCGGATCCGGCCAAGGCCAAGAAG; $\mu /$ trCRP3 5 , GACGGCGGATCCTCTAGAGGGCGCGGGCAAGAGG; C/EBP 3', GACGGCAAGCTTGCCTCACGCGCAGTTGCCCATGG; CRP1 3', GACGGCAAGCTTGGCTCAGCTGCAGCCCCC; CRP2 3', GACGGCAAGCTTGGGCTAGCAGTGACCCGC; CRP3 3', GACGGCAAGCTTGCGTTACCGGCAGTCGGC.
All hybrid constructs were expressed by using a modified Studier (Studier et al. 1990) T7 expression vector, pT5 (constructed by S. Eisenberg; see Landschulz et al. 1989) in strain BL21(DE3)pLysS. The parent plasmid for these constructs (pT5G $\mathrm{G}_{1} \mathrm{C}_{1}$ ) was described by Agre et al. (1989). Hybrid proteins were expressed and protein extracts were prepared as reported previously (Landschulz et al. 1989), except that the storage buffer (PBS) included 10\% glycerol. The overexpressed proteins were partially purified by heat treatment (incubation at $70^{\circ} \mathrm{C}$ for 10 min followed by sedimentation of insoluble material). In every case, the fusion protein remained in the soluble fraction and typically at this stage comprised $30-50 \%$ of the total protein.

\section{DNase I footprinting and gel retardation assays}

DNase I protection assays were carried out as described (Johnson et al. 1987) except that the stop buffer contained 200 $\mu \mathrm{g} / \mathrm{ml}$ of proteinase $\mathrm{K}$. Samples were incubated at $50^{\circ} \mathrm{C}$ for $1 \mathrm{hr}$ and ethanol-precipitated prior to loading onto an $8 \%$ sequencing gel. The two footprint probes were (1) a 180-bp HindIII-BgIII fragment of the rat albumin promoter, excised from the plasmid $\mathrm{p} \Delta \mathrm{EAlb}$ (kindly provided by S. Cereghini and $\mathrm{M}$. Yaniv) and end-labeled with polynucleotide kinase and $\left[\gamma^{-32} \mathrm{P}\right] \mathrm{ATP}$ at the upstream BglII site; and (2) a 400-bp HindIII-XbaI fragment of the HBV enhancer (described in Landschulz et al. 1988a) endlabeled at HindIII.

The probe for gel retardation assays was a double-stranded oligonucleotide homologous to nucleotides -107 to -90 of the rat albumin promoter (the DEI site), labeled with ${ }^{32} \mathrm{P}$ on the upper strand. Gel retardation reactions were carried out by the method of Fried and Crothers (1981), as modified by Nye and Graves (1990). Pairs of truncated and micro hybrid proteins, adjusted to give approximately equivalent binding activities, were mixed and incubated at $37^{\circ} \mathrm{C}$ for $30 \mathrm{~min}$ in the presence of $5 \mathrm{~mm}$ DTT. These mixtures were subsequently added to binding reactions that were placed at $4^{\circ} \mathrm{C}$ for $20 \mathrm{~min}$. Samples were electrophoresed on $5 \%$ polyacrylamide gels in $0.5 \times \mathrm{TBE}$ at $4^{\circ} \mathrm{C}$. The sequence of the DEI oligonucleotide was as follows:

\section{5'-TCGA CTATGATTTTGT AATGGGGC-3' 3'-GAT ACT AAAACATT ACCCCGAGCT-5'}

\section{Covalent dimerization assays}

Equal amounts of full-length and truncated proteins were mixed either in the absence or presence of $0.05 \mathrm{~mm}$ DTT. After $24 \mathrm{hr}$, the samples were mixed with loading buffer (Laemmli 1970) lacking $\beta$-mercaptoethanol and analyzed on $8 \%$ SDS-polyacrylamide gels. The kinetics of subunit exchange were determined by incubating $\mathrm{G}: \mathrm{C} / \mathrm{EBP}$ and $\operatorname{tr} G: \mathrm{C} / \mathrm{EBP}$ at $37^{\circ} \mathrm{C}$ in the presence of $0.05 \mathrm{mM}$ DTT. Aliquots were removed at various times and stored at $-70^{\circ} \mathrm{C}$ for later analysis by nonreducing SDSPAGE.

\section{Eukaryotic reporter and expression plasmids}

A fragment of the mouse albumin promoter containing nucleotides -787 to +8 plus 12 nucleotides from the HSV thymidine kinase (tk) $5^{\prime}$ leader was excised from the plasmid pAT2 (Zaret et al. 1988) with EcoRI and PstI. The EcoRI site was filled in with Klenow, and a HindIII linker was attached. This fragment was then inserted into the promoterless CAT plasmid pCATbasic (Promega, Inc.) to generate the reporter plasmid pAlbCAT.

C/EBP and CRP2 expression plasmids were constructed as 
follows. C/EBP-coding sequences were removed from the plasmid BS + N.C/EBP (Landschulz et al. 1989) by digestion with $B a m H I$ and KpnI. This fragment /containing a translational initiation adaptor sequence linked to the coding sequences of the rat $c / e b p$ gene) was inserted into the eukaryotic expression vector pMEX [B. Stanton, NCI-Frederick Cancer Research and Development Center (FCRDC)], to generate pMEXC/EBP. CRP2coding sequences were isolated from a rat genomic clone (pBSrsim2-3) by partial $\mathrm{NcOI}$ and complete EcoRI digestion to produce a 1550-bp fragment containing CRP2-coding and 3'untranslated sequences. This fragment was inserted into a pUC18-based plasmid that contains a NcoI cloning site (pUC112N; C. Petropoulos, NCI-FCRDC). The 1550-bp fragment was reisolated by partial $\mathrm{Ncol} / \mathrm{complete} H$ indIII digestion and inserted into $\mathrm{pBS}+\mathrm{N}$ (pBS $+\mathrm{N}$.C/EBP digested with $\mathrm{NcoI}$ and HindIII to remove C/EBP sequences). The CRP2-containing fragment was then isolated as a BamHI fragment and inserted into pMEX to generate pMEXCRP2.

\section{Cell culture and transfection}

Human hepatoma (HepG2) and HeLa cells were maintained in minimal Eagle medium (MEM; GIBCO or Mediatech, Inc.), supplemented with nonessential amino acids, sodium pyruvate, and $10 \%$ fetal calf serum (Hyclone, Inc.) in the presence of kanamycin, streptomycin, and penicillin. Transfections were carried out with $40 \%$ confluent monolayers in $10-\mathrm{cm}$ dishes by a standard calcium phosphate coprecipitation procedure (Graham and van der Eb 1973). In cotransfection experiments, a constant amount of pAlbCAT $(2 \mu \mathrm{g})$ was transfected with varying quantities of either pMEXC/EBP or pMEXCRP2. The total amount of transfected DNA was maintained at $17 \mu \mathrm{g}$ by adding nonspecific plasmid DNA. Each transfection was repeated at least three times, and the results were averaged. CAT analysis was carried out by standard procedures (Gorman et al. 1982) except that extracts were incubated at $65^{\circ} \mathrm{C}$ for $5 \mathrm{~min}$ and insoluble material was sedimented prior to analysis. All activities were normalized to that of pAlbCAT alone.

\section{Antibodies and immunoprecipitation assays}

Rabbit anti-C/EBP antiserum directed against a synthetic peptide containing amino acids $253-268$ has been described previously (Landschulz et al. 1988b). Rabbit anti-CRP2 antisera was generated by immunization with a peptide corresponding to amino acids 1-12 of CRP2. In a typical immunoprecipitation experiment, HepG2 cells were plated on day 0 at $2 \times 10^{7}$ to $3 \times 10^{7}$ cells per $150-\mathrm{mm}$ dish. On day 1 , the cells were transfected by using the calcium phosphate coprecipitation method, with either $40 \mu \mathrm{g}$ of $\mathrm{pMEXC/EBP}$ or pMEXCRP2 alone or with $20 \mu \mathrm{g}$ of each of the two plasmids. On day 2, the DNA precipitate was removed and the cells were incubated for $24 \mathrm{hr}$ in complete medium. On day 3, the medium was changed to Dulbecco's modified Eagle medium (DMEM) without L-methionine (GIBCO), supplemented with $10 \%$ dialyzed FBS (GIBCO). After $30 \mathrm{~min}, 50 \mu \mathrm{Ci} / \mathrm{ml}$ of $\left.{ }^{35} \mathrm{~S}\right]$ methionine was added, and the cells were incubated at $37^{\circ} \mathrm{C}$ for $18 \mathrm{hr}$. The cells were lysed in $3 \mathrm{ml}$ of high salt lysis buffer $[0.5 \mathrm{M} \mathrm{NaCl}, 0.1 \%$ Triton X-100, $50 \mathrm{~mm}$ Tris- $\mathrm{HCl}(8.0), 2 \mu \mathrm{g} / \mathrm{ml}$ of aprotinin, $60 \mu \mathrm{g} / \mathrm{ml}$ of PMSF], and lysates were prepared as described (Harlow and Lane 1988). Immunoprecipitation assays were carried out as described (Harlow and Lane 1988) with $3 \mu \mathrm{l}$ of undiluted antisera and $300 \mu \mathrm{l}$ of extract, and the immune complexes were precipitated by using protein A-Sepharose (Pharmacia). After washing, the pellet was resuspended in $30 \mu \mathrm{l}$ of Laemmli sample buffer, and $25 \mu \mathrm{l}$ of the supernatant was analyzed by $10 \%$ SDS-PAGE. The gel was fixed in $25 \%$ isopropanol, $10 \%$ acetic acid, enhanced in Amplify (Amersham), dried, and exposed to Kodak XAR film at room temperature.

\section{Western blotting}

Cell pellets from CAT assays were resuspended in $50 \mu \mathrm{l}$ of Laemmli buffer. The pellets were disrupted by sonication, and the cell debris was pelleted. Each sample $(25 \mu 1)$ was electrophoresed on $10 \%$ SDS-polyacrylamide gels. The gels were electroblotted onto nitrocellulose filters (Schleicher \& Schuell), and antibody-antigen complexes were visualized with the Promega ProtoBlot Alkaline Phosphatase Detection kit exactly as recommended by the supplier.

\section{Acknowledgments}

We thank Steve McKnight and Chuck Vinson for communicating unpublished results, John Burch and Ken Zaret for helpful discussions, Ken Zaret for supplying a mouse albumin promoter construct, Terry Copeland for antipeptide antisera, Marilyn Powers for oligonucleotides, Hilda Marusiodis for expert secretarial assistance, and the following people for comments on the manuscript: John Burch, Peter Donovan, Maggie Chamberlin, Benoit Arcangioli, Marge Strobel, and Yury Monczak. Research was sponsored by the National Cancer Institute, [Department of Health and Human Services (DHHS)], under contract NO1-CO74101 with Advanced Biosciences Laboratories. The contents of this publication do not necessarily reflect the views or policies of the DHHS, nor does mention of trade names, commercial products, or organizations imply endorsement by the U.S. government.

The publication costs of this article were defrayed in part by payment of page charges. This article must therefore be hereby marked "advertisement" in accordance with 18 USC section 1734 solely to indicate this fact.

\section{Note added in proof}

Cao et al. (this issue) report the isolation of two murine C/EBPlike genes, $c / e b p \beta$ and $c / e b p \gamma$. These genes are identical to $c r p 2$ and $\operatorname{crp} 3$, respectively. The nucleotide sequences of $\operatorname{crp} 1, \operatorname{crp} 2$, and crp 3 have been submitted to the EMBL/GenBank data base libraries.

\section{References}

Agre, P., P.F. Johnson, and S.L. McKnight. 1989. Cognate DNA binding specificity retained after leucine zipper exchange between GCN4 and C/EBP. Science 246: 922-925.

Akira, S., H. Isshiki, T. Sugita, O. Tanabe, S. Kinoshita, Y. Nishio, T. Nakajima, T. Hirano, and T. Kishimoto. 1990. A nuclear factor for IL-6 expression (NF-IL6) is a member of a C/EBP family. EMBO I. 9: 1897-1906.

Birkenmeier, E.H., B. Gwynn, S. Howard, J. Jerry, J.I. Gordon, W.H. Landschulz, and S.L. McKnight. 1989. Tissue-specific expression, developmental regulation, and genetic mapping of the gene encoding CCAAT/enhancer binding protein. Genes \& Dev. 3: 1146-1156.

Cereghini, S., M. Ramondjean, A. Garcia Carranca, P. Herbomel, and M. Yaniv. 1987. Factors involved in control of tissue-specific expression of albumin gene. Cell 50: 627638.

Chang, C.-J., T.-T. Chen, H.-Y. Lei, D.-S. Chen, and S.-C. Lee. 1990. Molecular cloning of a transcription factor, AGP/EBP, 
that belongs to members of the C/EBP family. Mol. Cell. Biol. 10: 6642-6653.

Christy, R.J., V.W. Yang, J.M. Ntambi, D.E. Geiman, W.H. Landschulz, A.D. Friedman, Y. Nakabeppu, T.J. Kelly, and M.D. Lane. 1989. Differentiation-induced gene expression in 3T3-L1 preadipocytes: CCAAT/enhancer binding protein interacts with and activates the promoters of two adipocytespecific genes. Genes \& Dev. 3: 1323-1335.

Church, G. and W. Gilbert. 1984. Genomic sequencing. Proc. Natl. Acad. Sci. 81: 1991-1995.

Clerc, R.G., L.M. Corcoran, J.H. LeBowitz, D. Baltimore, and P.A. Sharp. 1988. The B-cell-specific Oct-2 protein contains POU box- and homeo box-type domains. Genes \& Dev. 2: $1570-1581$.

Descombes, P., M. Chojkier, S. Lichsteiner, E. Falvey, and U. Schibler. 1990. LAP, a novel member of the C/EBP gene family, encodes a liver-enriched transcriptional activator protein. Genes \& Dev. 4: 1541-1551.

Devereux, J., P. Haeberli, and O. Smithies. 1984. A comprehensive set of sequence analysis programs for the VAX. Nucleic Acids Res. 12: 387-395.

Fried, M. and D.M. Crothers. 1981. Equilibria and kinetics of lac repressor-operator interactions by polyacrylamide gel electrophoresis. Nucleic Acids Res. 9: 6505-6525.

Friedman, A.D. and S.L. McKnight. 1990. Identification of two polypeptide segments of CCAAT/enhancer-binding protein required for transcriptional activation of the serum albumin gene. Genes \& Dev. 4: 1416-1426.

Friedman, A.D., W.H. Landschulz, and S.L. McKnight. 1989. CCAAT/enhancer binding protein activates the promoter of the serum albumin gene in cultured hepatoma cells. Genes \& Dev. 3: 1314-1322.

Galas, D. and A. Schmitz. 1978. DNase footprinting: A simple method for the detection of protein-DNA binding specificity. Nucleic Acids Res. 5: 3157-3170.

Gemtz, R., F.J. Rauscher III, C. Abate, and T. Curran. 1989. Parallel association of Fos and Jun leucine zippers juxtaposes DNA binding domains. Science 243: 1695-1699.

Gilbert, H.F. 1984. Redox control of enzyme activities by thiol/ disulfide exchange. Methods Enzymol. 107: 330-351.

Gonzalez, G.A., K.K. Yamamoto, W.H. Fischer, D. Karr, P. Menzel, W. Biggs III, W.W. Vale, and M.R. Montminy. 1989. A cluster of phosphorylation sites on the cyclic AMP-regulated nuclear factor CREB predicted by its sequence. Nature 337: 749-752.

Gorman, C.M., L.F. Moffat, and B.H. Howard. 1982. Recombinant genomes which express chloramphenicol acetyltransferase in mammalian cells. Mol. Cell. Biol. 2: 1044-1051.

Gorski, K., M. Carneiro, and U. Schibler. 1986. Tissue-specific in vitro transcription from the mouse albumin promoter. Cell 47: 767-776.

Graham, F.L. and A.J. van der Eb. 1973. Transformation of rat cells by DNA of human adenovirus 5. Virology 52: 456467.

Hai, T., F. Liu, W.J. Coukos, and M.R. Green. 1989. Transcription factor ATF cDNA clones: An extensive family of leucine zipper proteins able to selectively form DNA-binding heterodimers. Genes \& Dev. 3: 2083-2090.

Harlow, E. and D. Lane. 1988. Antibodies: A laboratory manual. Cold Spring Harbor Laboratory, Cold Spring Harbor, New York.

Herrera, R., H.S. Ro, G.S. Robinson, K.G. Zanthopoulos, and B. M. Spiegelman. 1989. A direct role for C/EBP and the AP-1binding site in gene expression linked to adipocyte differentiation. Mol. Cell. Biol. 9: 5331-5339.

Hoeffler, J.P., T.E. Meyer, Y. Yun, J.L. Jameson, and J.F.
Habener. 1988. Cyclic AMP-responsive DNA-binding protein: Structure based on a cloned placental cDNA. Science 242: 1430-1433.

Hope, I.A. and K. Struhl. 1987. GCN4, a eukaryotic transcriptional activator protein, binds as a dimer to target DNA. EMBO I. 6: 2781-2784.

Isshiki, H., S. Akira, O. Tanabe, T. Nakajima, T. Shimamoto, T. Hirano, and T. Koshimoto. 1990. Constitutive and interleukin-1 (IL-1)-inducible factors interact with the IL-1-responsive element in the IL-6 gene. Mol. Cell. Biol. 10: 2757-2764.

Iyer, S.V., D.L. Davis, S.N. Seal, and J.B.E. Burch. 1991. Chicken VBP, a leucine zipper transcription factor that binds to an important control element in the chicken vitellogenin II promoter, is related to rat DBP. (in press).

Johnson, P.F. and S.L. McKnight. 1989. Eukaryotic transcriptional regulatory proteins. Annu. Rev. Biochem. 58: 799839.

Johnson, P.F., W.H. Landschulz, B.J. Graves, and S.L. McKnight. 1987. Identification of a rat liver nuclear protein that binds to the enhancer core element of three animal viruses. Genes \& Dev. 1: 133-146.

Jones, N.C., P.W.J. Rigby, and E.B. Ziff. 1988. Trans-acting protein factors and the regulation of eukaryotic transcription: Lessons from studies on DNA tumor viruses. Genes \& Dev. 2: $267-281$.

Kouzarides, T. and E. Ziff. 1988. The role of the leucine zipper in the fos-jun interaction. Nature 336: 646-651.

. 1989. Leucine zippers of fos, iun, and GCN4 dictate dimerization specificity and thereby control DNA binding. Nature 340: 568-571.

Laemmli, U.K. 1970. Cleavage of structural protein during the assembly of the head of bacteriophage T4. Nature 277: 680685.

Landschulz, W.H., P.F. Johnson, and S.L. McKnight. 1988a. The leucine zipper: A hypothetical structure common to a new class of DNA binding proteins. Science 240: 1759-1764.

Landschulz, W.H., P.F. Johnson, E.Y. Adashi, B.J. Graves, and S.L. McKnight. 1988b. Isolation of a recombinant copy of the gene encoding C/EBP. Genes \& Dev. 2: 786-800.

Landschulz, W.H., P.F. Johnson, and S.L. McKnight. 1989. The DNA binding domain of the rat liver nuclear protein C/EBP is bipartite. Science 243: 1681-1688.

Lichsteiner, S., J. Wuarin, and U. Schibler. 1987. The interplay of DNA-binding proteins on the promoter of the mouse albumin gene. Cell 51: 963-973.

Majello, B., R. Arcone, C. Toniatti, and G. Ciliberto. 1990. Constitutive and IL-6-induced nuclear factors that interact with the human C-reactive protein promoter. EMBO I. 9: 457465.

Maniatis, T., S. Goodbourn, and J.A. Fischer. 1987. Regulation of inducible and tissue-specific gene expression. Science 236: $1237-1245$.

Mueller, C.R., P. Maire, and U. Schibler. 1990. DBP, a liverenriched transcriptional activator, is expressed late in ontogeny and its tissue specificity is determined posttranscriptionally. Cell 61: 279-291.

Muller, M.M., T. Gerster, and W. Schaffner. 1988. Enhancer sequences and the regulation of gene transcription. Eur. J. Biochem. 2: 267-281.

Nye, J.A. and B.J. Graves. 1990. Alkylation interference identifies essential DNA contacts for sequence-specific binding of the eukaryotic transcription factor C/EBP. Proc. Natl. Acad. Sci. 87: 3992-3996.

Pei, D. and C. Shih. 1991. An "attenuator domain" is sandwiched by two distinct transactivation domains in the transcription factor C/EBP. Mol. Cell. Biol. 11: 1480-1487. 
Poli, V. and R. Cortese. 1989. Interleukin 6 induces a liverspecific nuclear protein that binds to the promoter of acutephase genes. Proc. Nat1. Acad. Sci. 86: 8202-8206.

Poli, V., F.P. Mancini, and R. Cortese. 1990. IL-6DBP, a nuclear protein involved in interleukin- 6 signal transduction, defines a new family of leucine zipper proteins related to C/EBP. Cell 63: 643-653.

Roman, C., J.S. Platero, J. Shuman, and K. Calame. 1990. Ig/ EBP-1: A ubiquitously expressed immunoglobulin enhancer binding protein that is similar to C/EBP and heterodimerizes with C/EBP. Genes \& Dev. 4: 1404-1415.

Rosner, M.H., M.A. Vigano, K. Ozato, P.M. Timmons, F. Poirier, P.W.J. Rigby, and L.M. Staudt. A POU-domain transcription factor in early stem cells and germ cells of the mammalian embryo. 1990. Nature 345: 686-692.

Scholer, H.R., A.K. Hatzopoulos, R. Balling, N. Suzuki, and P. Gruss. 1989. A family of octamer-specific proteins present during mouse embryogenesis: Evidence for germline-specific expression of an Oct factor. EMBO /. 8: 2543-2550.

Sellers, J.W. and K. Struhl. 1989. Changing Fos oncoprotein to a Jun-independent DNA-binding protein with GCN4 dimerization specificity by swapping "leucine zippers." Nature 341: 74-76.

Singh, H., J.H. LeBowitz, A.S. Baldwin, Jr., and P.A. Sharp. 1988. Molecular cloning of an enhancer binding protein: Isolation by screening of an expression library with a recognition site DNA. Cell 52: 415-423.

Studier, F.W., A.H. Rosenberg, J.J. Dunn, and J.W. Dubendorff. 1990. Use of T7 RNA polymerase to direct expression of cloned genes. Methods Enzymol. 185: 60-89.

Sturm, R.A., G. Das, and W. Herr. 1988. The ubiquitous octamer-binding protein Oct-1 contains a POU domain with a homeo box subdomain. Genes \& Dev. 2: 1582-1599.

Turner, R. and R. Tjian. 1989. Leucine repeats and an adjacent DNA binding domain mediate the formation of functional cFos-cIun heterodimers. Science 243: 1689-1694.

Umek, R.M., A.D. Friedman, and S.L. McKnight. 1991. CCAAT-enhancer binding protein: A component of a differentiation switch. Science 251: 288-292.

Vinson, C.R., P.B. Sigler, and S.L. McKnight. 1989. Scissors-grip model for DNA recognition by a family of leucine zipper proteins. Science 246: 911-916.

Weintraub, H., R. Davis, S. Tapscott, M. Thayer, M. Krause, R. Benezra, T.K. Blackwell, D. Turner, R. Rupp, S. Hollenberg, Y. Zhuang, and A. Lassar. 1991. The myoD gene family: Nodal point during specification of the muscle cell lineage. Science 251: 761-766.

Yon, J. and M. Fried. 1989. Precise gene fusion by PCR. Nucleic Acids Res. 17: 4895

Zaret, K.S., C.M. DiPersio, D.A. Jackson, W.J. Montigny, and D. L. Weinstat. 1988. Conditional enhancement of liver-specific gene transcription. Proc. Natl. Acad. Sci. 85: 90769080.

Ziegler, D.M. 1985. Role of reversible oxidation-reduction of enzyme thiols-disulfides in metabolic regulation. Annu. Rev. Biochem. 54: 305-329.

Ziff, E.B. 1990. Transcription factors: A new family gathers at the cAMP response site. Trends Genet. 6: 69-72. 


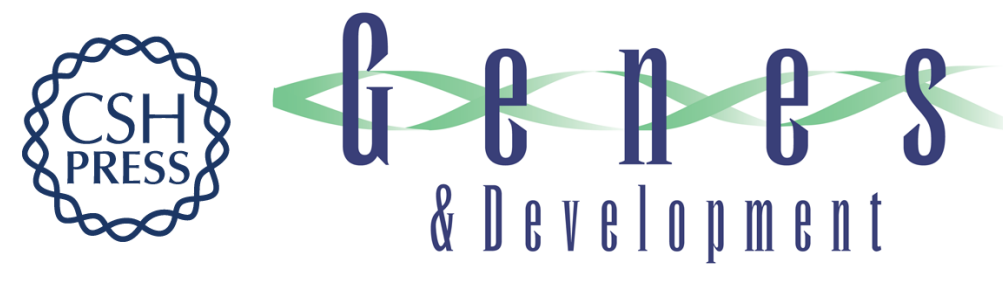

\section{A family of C/EBP-related proteins capable of forming covalently linked leucine zipper dimers in vitro.}

S C Williams, C A Cantwell and P F Johnson

Genes Dev. 1991, 5:

Access the most recent version at doi:10.1101/gad.5.9.1553

References This article cites 58 articles, 31 of which can be accessed free at: http://genesdev.cshlp.org/content/5/9/1553.full.htmI\#ref-list-1

License

Email Alerting

Receive free email alerts when new articles cite this article - sign up in the box at the top Service right corner of the article or click here.

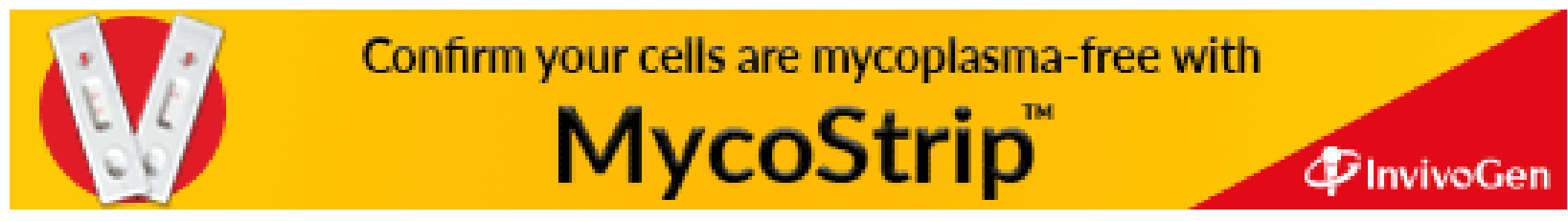

